\title{
Preliminary phytochemical screening and antibacterial activity of thaumatococcus daniellii (Benn.) benth. (Marantaceae) leaf extract
}

\begin{abstract}
Thaumatococcus daniellii been used in Nigeria as food sweetener especially in Southeastern Nigeria as well as wrapping leaf for locally processed food called "Agidi". This present study was aimed at screening the leaf ethanol extract for some constituents and evaluating the leaf for the antibacterial property. The result of preliminary phytochemical showed the presence of carbohydrate, glycosides (free anthracene, cardiac glycosides, saponins, and flavonoids), tannins, and alkaloids. Antibacterial screening of crude leaf extract by agar well diffusion method against selected bacterial strains; Bacillus subtilis ATCC 12432, Streptococcus pyogenes ATCC 8668, Shigella dysenteriae (clinical isolate), Campylobacter jejuni, Salmonella typhi ATCC23564, and Staphylococcus aureus ATCC29213 revealed that the leaf was potent on the microbes. This was comparable to diameter zone of inhibition of standard antibiotics (ciprofloxacin USP) and distil water were used as the positive and negative controls respectively at $p \leq 0.05$ (one-way ANOVA). The result showed that $S$. typhi had highest diameter zone of inhibition of $58 \pm 0.11 \mathrm{~mm}$; $\mathrm{MIC}$ and $\mathrm{MBC}$ of $10 \mathrm{mg} / \mathrm{mL}$ and $20 \mathrm{mg} / \mathrm{mL}$ respectively while $S$. dysenteriae displayed the least zone of inhibition of $29 \pm 0.09 \mathrm{~mm}$ against the extract. Hence the study showed that $T$. daniellii possess antibacterial properties against the bacterial strains. The plant extract was more effective on Gram-negative bacterial than Gram-positive bacterial.
\end{abstract}

Volume 4 Issue 2 - 2017

\author{
Cletus A UKwubile,' Ikpefan E Oise, ${ }^{2}$ Julius T \\ Nyiayem $^{3}$ \\ IDepartment of Science Laboratory Technology, Federal \\ Polytechnic Bali School of Science and Technology, Nigeria \\ ${ }^{2}$ Department of Pharmacognosy and Traditional Medicine, Delta \\ State University, Nigeria \\ ${ }^{3}$ Department of Chemistry, Federal University of Agriculture \\ Makurdi, Nigeria
}

Correspondence: Hyacinth OU, Department of Public Health, Saudi Electronic University, PO Box 93499, Riyadh II673, Saudi Arabia, Tel +966 I I 26 I3500, Fax +966 I | 26 I3578 Email hyacoo2000@yahoo.com

Received: October 24, 2016 | Published: February 22, 2017

Keywords: thaumatococcus daniellii, ciprofloxacin, agar well diffusion, gram-negative bacteria, molisch test

\section{Introduction}

The sweet prayer plant (Thaumatococcus daniellii) is a rhizomatous plant found in tropical rain forest and coastal areas of West Africa particularly Nigeria, Ghana and Cote d'Ivoire. ${ }^{1}$ It belongs to the family Marantaceae. It has long slender stalks that can grow up to $2-3 \mathrm{~m}$ high, each bearing a single tough, ovoid shape leaf of varying size depending on the plant's age and habitat. ${ }^{2}$

Thaumatococcus daniellii whether cultivated or in the wild contribute to the economy of the rural people in most part of Southern Nigeria through its stalks, leaves, fruits and rhizomes. ${ }^{3,4}$ The economic prospect of the fruits is currently engaging the attention of researchers, farmers and industries in the West African region. It has wide application in foods and drinks particularly in the area of taste modification and flavor enhancement. Thaumatin is a natural protein sweetener and readily decomposes into the natural distribution of amino acid upon hydrolysis. It is non-caloric, non-toxic and widely accepted as safe by regular authorities.$^{5}$

This study was carried out in order to determine the phytochemical constituents and antibacterial activity of the leaf ethanol extract.

\section{Materials and methods}

\section{Materials}

The following materials were used in this study: Plant extract, blood agar, test tube, Petri dishes, absolute ethanol, distilled water, measuring cylinder, McFarland no 0.5 turbidity scale, cork-borer $5 \mathrm{~mm}$ diameter, and Salmonella tyhpi ATCC23564, Shigella dysenteriea, Staphylococcus aureus ATCC29213, Campylobacter jejuni, Bacillus subtilis ATCC12432, and Streptococcus pyogenes ATCC8668. All bacterial strains were obtained on purchase from the National Research Institute for Chemical Technology, Bassawa Zaria, Nigeria in frozen form.

\section{Methods}

Collection and identification of plant: Fresh mature leaves $T$. daniellii were collected in May 2016 from a bush located in Takum Local Government Area, Taraba State, Nigeria. The authentication of the plant was made by Mr. Cletus A.U. a taxonomist in the Department of Science Laboratory Technology Federal. Polytechnic Bali where a voucher number of MAR001 was deposited for the plant.

Extraction of plant material: The fresh plant was washed thoroughly with tap water followed by distilled water in order to remove any dirt or filthy particles present on the surface and were air-dried under a shaded condition at room temperature for 14days. The dried plant was grind using an electronic blender into powdered form.

\section{Preliminary phytochemical screening of leaf ethanol extract}

The extract was tested for the presence of bioactive metabolites using a standard method of. ${ }^{6}$

\section{Test for carbohydrate}

Molisch test: Few drops of Molisch reagent was added to a little quantity of extract in a test tube and a small quantity of concentrated sulphuric acid was allowed to run down, the slide of the test tube to from a lower. A purple to violet color at the interphase indicate the presence of carbohydrate. 
Fehling test: $2 \mathrm{~mL}$ of extracts, $5 \mathrm{~mL}$ of a mixture of Fehling solution $\mathrm{A}$ and $\mathrm{B}$ in the ratio of 1:1 was added and the mixture boiled for fewminutes. Brick red precipitates indicate the presence of free reducing sugar.

Test for glycosides (General test): $5 \mathrm{~mL}$ of conc. sulphuric acid was added to the extract and boiled for 15 minutes. This was then cooled and neutralized with $20 \%$ potassium hydroxide and was divided into 2 portions another part of the extract was dissolved in distilled water, this was used as a control; no acid hydrolysis.

Fehling solution test: The Fehling solution A and B was added to this portion and boiled for few minutes. A brick red precipitate indicates the glycone portion as a result of hydrolysis of glycoside

Ferric chloride test: Few drops of ferric chloride solution were added to this portion. Green to black precipitate indicates Phenolic aglycones as a result of hydrolysis of glycosides.

\section{Test for anthraquinone derivatives}

Test for free anthraquinones (Borntrager's test): A small portion of the extract was shocked with $10 \mathrm{~mL}$ of benzene and filtered $5 \mathrm{~mL}$ of $10 \%$ of ammonia solution was added to the filtrate and stirred. The productions of a pink-red or violet color indicate the presence of free anthraquinones.

Test for combine anthracene (Modified Borntrager's test): The sample was boiled with $5 \mathrm{~mL}$ of $10 \%$ hydrochloric acid for 3 minutes. This will hydrolyze the glycoside to yield aglycones which are soluble in hot water only. The solution was filtered hot. The filtrate was cooled and extracted with $5 \mathrm{~mL}$ of benzene. The benzene layer was filtered off and shaken gently with half its volume of $10 \%$ ammonia solution. A rose-pink or a cherry recolor indicates combined anthracene.

\section{Test for cardiac glycosides}

Kella-killiani test: The extract was dissolved in glacial acetic acid containing traces of Ferric chloride. The test tube was held at an angle of 45 degrees, $1 \mathrm{~mL}$ of concentrated sulphuric acid was added down the side. Purple ring color at the interface indicates cardiac glycosides.

Kadde test: $1 \mathrm{~mL}$ of $2 \% 3$, the 5-dinitrobenzoic acid in 95\% alcohol was added to the extract. The solution was made alkaline with $5 \%$ sodium hydroxide. The appearance of purple-blue color indicates the presence of cardenolides in the ring.

Salkowsk test: To about $0.5 \mathrm{~g}$ of the extract was dissolved in $2 \mathrm{~mL}$ of chloroform and few drops of concentrated $\mathrm{H} 2 \mathrm{SO} 4$ were added to form a lower layer. A reddish-brown color at interface indicates the presence of a steroidal ring.

\section{Test saponins}

Frothing test: A small quantity of the extract was dissolved in $10 \mathrm{~mL}$ of distilled water. This was then shaken vigorously for 30 seconds and was allowed to stand for 30 minutes. A honey comb formed for more than 30 minutes indicates saponins.

Test for steroid and triterpenes (Lieberman-Bucchard test): Equal volume and acetic anhydride were added to the extract $1 \mathrm{~mL}$ of concentrated $\mathrm{H} 2 \mathrm{SO} 4$ was added down side the tube. The color change was observed immediately and later. Red, pink or purple color indicates the presence of triterpenes while blue or blue-green indicates steroids.

\section{Test for flavonoids}

Shinoda's Test: About $0.5 \mathrm{~g}$ of the extract was dissolved in $2 \mathrm{~mL}$ of
$50 \%$ methanol in the heat. Metallic magnesium and 4-5 drops of conc. $\mathrm{HCl}$ was added. A red or orange color indicates the presence of flavanoic aglycones.

Sodium hydroxide test: Few drops of aqueous $\mathrm{NaOH}$ were added to $5 \mathrm{~mL}$ of extract, a yellow coloration shows the presence of flavonoids.

\section{Test for tannins}

Lead subacetate test: Three drops of lead-sub acetate solution were added to a solution of the extract. A brown precipitate indicates tannins.

Ferric chloride test: About $0.5 \mathrm{~mL}$ of the extract was dissolved in $10 \mathrm{~mL}$ of distilled water and then filtered. Few drops of Ferric chloride solution were added to the filtrate. Formation of a blueblack precipitate indicates hydrolysable tannins and green precipitate indicates the presence of condensed tannin.

\section{Test for alkaloids}

Dragendorff's test: Few drops of this reagent were added to the extract. Rose red precipitate indicates the presence of alkaloid.

Wagner's test: Few drops of this reagent were added to the small amount of the extract. Whitish precipitate indicates alkaloid.

Picric acid test: Few drops of $1 \%$ picric acid solution were added to the extract. Yellow colored solution indicates alkaloids.

Tannic acid test: Few drops of Tannic acid were added to a sample of the extract. Black precipitate indicates the presence of alkaloids.

\section{Antibacterial screening of leaf ethanol extract}

\section{Preparation of culture media}

The media was prepared by weighing $3.3 \mathrm{~g}$ of the nutrient agar from the stock container and was dissolved in $120 \mathrm{~mL}$ of distilled water, nutrient agar used to culture the microorganism isolates. The media was sterilized in the autoclave at $121^{\circ} \mathrm{C}$ and 15 minutes for the composition and preparation of media. The prepared media was then poured into the Petri dish and left to solidify.

\section{Susceptibility study of leaf ethanol extract against the microbes}

Agar well diffusion method was used for the study. Briefly, blood agar plate was swabbed (using sterile swab stick with an agar slant culture of bacteria. Four wells ( $5 \mathrm{~mm}$ in diameter and about $2 \mathrm{~cm}$ apart) were made in each of these plant using sterile cork borer. A stock solution of the plant extract was prepared with sterile distilled water. $2 \mathrm{~mL}$ of the extract was added each into 2 of the wells, and the same amount of the standard solution (ciprofloxacin) was added in each of the wells using a sterile syringe. A control experiment comprising inoculums with sterile distilled water into the well was set-up and was allowed to diffuse at room temperature for 20-30minutes. The plates were incubated (not upside down) at $37^{\circ} \mathrm{C} \pm 2^{\circ} \mathrm{C}$ for 24 hours. The diameter zone of inhibition $(\mathrm{mm})$ was measured using a transparent ruler. The zero end of the ruler was placed from one end of the zone of inhibition to another, ensuring that the ruler divides the well into two equal halves (that is, passing through the center of the wells).

\section{Determination of minimum inhibitory concentration (MIC)}

The MIC was carried out on the microorganism that shows sensitivity to the extract this was done using brought dilution 
method. ${ }^{7,8}$ The aim was to know the least concentration of the extract that will inhibit or prevent the growth of the bacteria. Nutrient brought was prepared according to the manufacturer instructions. Ions of the broth were disposed into 5 test-tube each for the bacteria and sterilized at $121^{\circ} \mathrm{C}$ for 15 minutes. McFarland turbidity standard scale number 0.5 was prepared to give a turbid suspension of the microorganism. Normal saline was also prepared. The microbes were inoculated into the normal saline until the turbidity marched that of the McFarland scale by visual comparison. At this point, the microbes have a concentration of $1.5 \times 108 \mathrm{cfamL}$. Dilution of the extracts in the nutrient broth was done for each set of the organisms to obtain concentrations of $20 \mathrm{mg} / \mathrm{mL} 10 \mathrm{mg} / \mathrm{mL}, 5 \mathrm{mg} / \mathrm{mL} 2.5 \mathrm{mg} / \mathrm{mL}$ and $1.25 \mathrm{mg} / \mathrm{mL}$. Using a sterile pipette, $0.2 \mathrm{~mL}$ of the microbe suspension was transferred into each test tube and then incubated at $37^{\circ} \mathrm{C}$ for 24 hours. The tubes were observed for turbidity or growth. Test tube with the lowest concentration of the extract showing a clear solution (no turbidity) was regarded as the MIC.

\section{Determination of minimum bactericidal concentration (MBC) of the extract}

The MBC was carried out to determine whether the microbes were killed or only their growth was inhibited. Blood agar was prepared according to the manufacturer's instructions and sterilized at $121^{\circ} \mathrm{C}$ for 15 minutes. It was poured into sterile Petri dishes and left to solidify. The plates were labeled accordingly to correspond to the
MIC test tube. The content of the MIC in the proceeding test tubes in the serial dilution was sub-cultured into the plates. By dipping a sterile wire loop and streaking the surface of the agar in the plates. The plates were then incubated at $37^{\circ} \mathrm{C}$ for 24 hours after which they were checked for growth. The plate with the lowest concentration of extract without growth was taken as the MBC.

\section{Statistical analysis}

The data obtained were analyzed using graph pad prism version 7 2016, while significant difference were compared at $\mathrm{p} \leq 0.05$ (one-way ANOVA).

\section{Results and discussion}

In the phytochemical screening of the leaf ethanol extract which have yielded $6.0 \%(\mathrm{w} / \mathrm{w})$ showed the presence of saponins, flavonoids, carbohydrates, as well as tannins and alkaloids (Table1). These chemical constituents contributed to the biological activities of the leaf as was observed (Table 2). Saponins are a special class of glycosides with soapy characteristics. ${ }^{9}$ Tannins have been reported to prevent the development of microorganism by precipitating microbial protein and making nutritional proteins unavailable for the. ${ }^{10}$ This assertion was not different from the observed antibacterial activity where the extract showed high level of activity on Salmonella typhi when compared with other bacteria.

Table I Result of phytochemical screening of the ethanol extract of Thaumatococcus daniellii

\begin{tabular}{|c|c|c|c|}
\hline Constituents & Test & Observation & Inference \\
\hline \multirow[t]{2}{*}{ Carbohydrate } & Molisch test & Purple to violet & + \\
\hline & Fehling's test & No color change & - \\
\hline \multirow{2}{*}{ Glycoside } & Fehling's solution test & Brick red & ++ \\
\hline & Ferric chloride test & Green to black & ++ \\
\hline Anthraquinone & Borntrager's test & No color change & - \\
\hline Anthracene & Modified Borntrager's test & Cherry red & + \\
\hline \multirow[b]{2}{*}{ Cardiac glycoside } & Kella-killiani & Purple ring color & + \\
\hline & Kadde's test & Purple blue & ++ \\
\hline \multirow[b]{2}{*}{ Saponins } & Frothing test & Honey comb & ++ \\
\hline & Steroids and triterpenes & Pink purple & ++ \\
\hline \multirow[b]{2}{*}{ Flavonoids } & Shinoda's test & Red & ++ \\
\hline & $\mathrm{NaOH}$ & Yellow & ++ \\
\hline \multirow{2}{*}{ Tannins } & Lead sub- acetate & Brown & + \\
\hline & Ferric chloride & Blue black & ++ \\
\hline \multirow{4}{*}{ Alkaloids } & Dragendorff's test & Rose red & ++ \\
\hline & Wagner's test & No color change & - \\
\hline & Picric acid & Yellow color & + \\
\hline & Tannic acid & Black color & ++ \\
\hline
\end{tabular}

-, not detected; +, detected in trace amounts; ++, detected in high amount 
Table 2 Diameter zone inhibition of leaf extract against the bacteria

\begin{tabular}{lll}
\hline Test organism & \multicolumn{2}{l}{ Diameter zone of inhibition (mm) \pm SEM } \\
\hline Bacillus subtilis ATCCI2432 & Extract & Ciprofloxacin \\
Streptococcus pyogens ATCC8668 & $42 \pm 0.11$ & $39 \pm 0.10$ \\
Shigella dysenteriae (clinical isolate) & 300.09 & $37 \pm 0.6$ \\
Campylobacter jejuni (clinical isolate) & $29 \pm 0.09$ & $32 \pm 0.09$ \\
Salmonella typhi ATCC23564 & $57 \pm 0.12$ & 0 \\
Staphylococcus aureus ATCC29213 & $58 \pm 0.11$ & $41 \pm 0.11$ \\
\hline
\end{tabular}

The extract evaluated showed antibacterial activity against certain Gram-positive (Staphylococcus aureus ATCC29213) and Gramnegative (Bacillus substilis ATCC12432, Streptococcus pyogenes ATCC8668, Shigella dysenteriae (clinical isolate) Campylobacter jejuni (clinical isolate) Salmonella typhi ATCC23564) bacteria.
It can then be said that the fact that Thaumatococcus daniellii inhibited the growth of the bacteria in vitro meant that the plant extract can be used to treat a disease that is caused by these bacteria such as typhoid fever by Salmonella typhi, Staphylococcus aureus staphylococcus infection and early abortion caused by Campylobacter jejuni (Tables 1-3).

Table 3 Minimum inhibitory concentration and minimum bactericidal concentration $(\mathrm{mg} / \mathrm{mL})$ of extracts against bacteria.

\begin{tabular}{|c|c|c|c|c|c|c|c|c|c|c|}
\hline \multirow[t]{2}{*}{ Organism } & \multicolumn{5}{|c|}{ MIC } & \multicolumn{5}{|c|}{ MBC } \\
\hline & 20 & 10 & 5 & 2.5 & I.25 & 20 & 10 & 5 & 2.5 & 1.25 \\
\hline Bacillus subtilis ATCC 12432 & - & - & - & O* & ++ & - & - & Oa & + & ++ \\
\hline Streptococcus pyogenesATCC8668 & - & - & $\mathrm{O}^{*}$ & + & ++ & - & $\mathrm{Oa}$ & + & ++ & +++ \\
\hline Shigella dysenteriae (clinical isolate) & - & - & - & - & O* & - & - & - & $\mathrm{Oa}$ & +++ \\
\hline Campylobacter jejuni (clinical isolate) & - & O* & + & ++ & +++ & $\mathrm{Oa}$ & + & ++ & +++ & +++ \\
\hline Salmonella typhi ATCC 23564 & - & O* & + & ++ & +++ & $\mathrm{Oa}$ & + & ++ & +++ & +++ \\
\hline Staphylococcus aureus ATCC292 I 3 & - & - & $\mathrm{O}^{*}$ & ++ & +++ & - & $\mathrm{Oa}$ & + & ++ & +++ \\
\hline
\end{tabular}

-,clear; O*, MIC; Oa, MBC; +, light growth; ++, moderate growth; +++, dense growth

\section{Conclusion}

Extract of Thaumatococcus daniellii posses broad-spectrum antibacterial activity against both Gram-positive and Gram-negative bacteria .The broad-spectrum antibacterial activities of the plant extract was possibly due to the identified alkaloids, flavonoids, tannins. Thus, confirm its use as health remedy in traditional medicine. Bioactive substance from this plant can, therefore, be employed in the formulation of antibacterial agent for the treatment of various bacterial infections including gonorrhea, pneumonia, eye infections, typhoid, early abortion and staphylococcus infections etc.

Further studies should be carried out on the isolation, purification and the toxicological studies of the leaf extract in an attempt to determine the exact component responsible for the observed biological activity (antibacterial) with the view to formulating novel chemotherapeutic agents with antibacterial activity.

\section{Acknowledgements}

We are very thank ful to Mr. Mika Nurah of the National Institute for Chemical Research Technology (NARICT) Bassawa Zaria who supplied the microbes used in this study.

\section{Conflict of interest}

The author declares no conflict of interest.

\section{References}

1. Yeboah SO, Hilger TH, Krochel J. Thaumatococcus danieli (Benth): a natural sweetener from the rain forest zone in west Africa with potential, income generation in the small scale farming. J Applied Sci. 2003;6:854 859.

2. Makinde SCO, Taiwo CKT. In situ population Evaluation of Thaumatococcus danieli (Benth). Asian International Journal of Plant Science. 2004;3(1):5-80.

3. Arowosage OGE, Popoola L. Economic analysis of $T$. daniellii (Miraculous berry) in Ekiti State Nigeria. J food Agric Environment. 2006;4(1):264-269.

4. Osemebo JG. Living on wild plant Evaluation of the rural house hold economy in the Nigeria. Cambridge J. 2005;7(4):246-256.

5. Zemanek EC, Wasserman BP. Issues and production of thaumatin the intensely sweet protein from Thaumatoccus daniellii. Crit Rev food Sci Nutr. 1995;35(5):455-466.

6. Evans WC. Trease and Evans Pharmacognosy. 16th ed. UK: Saunders Elsevier Publishers; 2009. 513 p. 
7. Bauer AW. Antibiotic susceptibility testing by a standardized single disc Method. Am J Clin Pathol. 1996;45(4):496-502.

8. Ukwubile CA, Nuhu IH. Pharmacognostic, antibacterial and toxicity investigations of ficus abutilifolia Miq. (Moraceae). International Journal of Biological Science. 2010;8(2):59-63.
9. Fluck H. Medicinal plants and their uses. USA: W Fulsome and Comp Ltd; 2013. p. 7-15.

10. Aliyu R, Adebayo RH, Gatsing D, et al. The effects of ethanol leaf extract of Thaumatococcus daniellii (Marantaceae) on rat liver and kidney functions. Journal of Pharmacology and Toxicology. 2008;2:373-379. 